\title{
SPILLOVERS FROM COSTLY CREDIT
}

by

\author{
Brian T. Melzer \\ Department of Finance \\ Kellogg School of Management
}

\begin{abstract}
CES 13-11
March, 2013

The research program of the Center for Economic Studies (CES) produces a wide range of economic analyses to improve the statistical programs of the U.S. Census Bureau. Many of these analyses take the form of CES research papers. The papers have not undergone the review accorded Census Bureau publications and no endorsement should be inferred. Any opinions and conclusions expressed herein are those of the author(s) and do not necessarily represent the views of the U.S. Census Bureau. All results have been reviewed to ensure that no confidential information is disclosed. Republication in whole or part must be cleared with the authors.

To obtain information about the series, see www.census.gov/ces or contact Fariha Kamal, Editor, Discussion Papers, U.S. Census Bureau, Center for Economic Studies 2K132B, 4600 Silver Hill Road, Washington, DC 20233, CES.Papers.List@census.gov.
\end{abstract}




\begin{abstract}
Recent research on the effects of credit access among low- and moderate-income households finds that high-cost payday loans exacerbate, rather than alleviate, financial distress for a subset of borrowers (Melzer 2011; Skiba and Tobacman 2011). In this study I find that others, outside the borrowing household, bear a portion of these costs too: households with payday loan access are $20 \%$ more likely to use food assistance benefits and $10 \%$ less likely to make child support payments required of non-resident parents. These findings suggest that as borrowers accommodate interest and principal payments on payday loan debt, they prioritize loan payments over other liabilities like child support payments and they turn to transfer programs like food stamps to supplement the household's resources. To establish this finding, the analysis uses a measure of payday loan access that is robust to the concern that lender location decisions and state policies governing payday lending are endogenous relative to household financial condition. The analysis also confirms that the effect is absent in the mid1990s, prior to the spread of payday lending, and that the effect grows over time, in parallel with the growth of payday lending. ${ }^{\text {i }}$
\end{abstract}

'I thank Lindsey Leininger, Annamaria Lusardi and David Matsa for helpful feedback. The research in this paper was conducted while Melzer was a Special Sworn Status researcher of the U.S. Census Bureau at the Chicago Census Research Data Center. Any opinions and conclusions expressed herein are those of the author(s) and do not necessarily represent the views of the U.S. Census Bureau. All results have been reviewed to ensure that no confidential information is disclosed. 


\section{Introduction}

The expansion of credit to low- and moderate-income households in the United States was a notable development of the 2000s, with substantial growth not only in mortgage credit but also in short-term, unsecured credit: overdraft loans provided by banks and cash advances provided by so-called payday lenders. Recent experience in the housing market suggests that there were substantial spillover costs from the mortgage credit boom, costs borne by taxpayers who have funded mortgage modification subsidies and bank bailouts, and by neighbors whose home values have declined with nearby foreclosures (Campbell, Giglio and Pathak 2011). The goal of this paper is to examine the importance of spillover costs for short-term credit by testing whether food stamp participation and child support payments vary with payday loan access.

There has been considerable debate about whether payday lending alleviates or exacerbates financial distress. In principle, access to credit can improve welfare by allowing households to smooth expenditures through periods of income and consumption shocks. But payday loans are also quite expensive, with a typical bi-weekly fee of $\$ 15$ per $\$ 100$ borrowed. Given these high costs, borrowing to increase current consumption can exacerbate hardship in the future, especially among individuals with forecasting or self-control problems (Ausubel 1991; Laibson 1997; Bond, Musto and Yilmaz 2009).

Though results vary across studies, there is evidence that the expansion of payday credit exacerbates financial difficulties, at least for a subset of borrowers: rather than allowing households to pay important bills and forestall bankruptcy, payday loans exacerbate their difficulty in paying mortgage, rent and utilities bills (Melzer 2011) and increase their likelihood of filing bankruptcy (Skiba and Tobacman 2011). Among military personnel, payday loan access 
worsens job performance and readiness (Carrell and Zinman 2008). This evidence suggests that loan access is costly rather than beneficial for some households.

This study probes more deeply into who bears these costs. Clearly the borrower and others within the household bear some cost as they fall short on bill payments. In this analysis, I find that others outside of the household share the burden as well, as households with proximate access to payday loans are $20 \%$ more likely to use food stamps and $10 \%$ less likely to make child support payments. The increase in food stamp receipt helps explain why measures of foodrelated hardship - cutting back on quantity or quality of meals due to lack of money - show no significant increase with payday lending despite increased hardship along other dimensions. These findings suggest that as borrowers adjust their other expenditures to accommodate interest and principal payments on payday loan debt, they turn to transfer programs like food stamps to supplement the household's resources and they prioritize loan payments over other liabilities like child support payments.

The analysis follows Melzer (2011) in using geographic variation in payday loan access that does not depend on cross-state comparisons. The study design relies on the fact that loan access varies among households in states that prohibit payday lending: households residing close to a payday-allowing state can borrow at stores across the border, while households far from the border face more limited access. Isolating within-state variation is important because of the considerable variation in food stamp participation across states and the noteworthy trends in food stamp participation during the study period. Accordingly, an empirical design that uses crossstate comparisons or that traces changes around state payday loan prohibitions is ill suited; it is quite possible that other differences will confound the variation in payday lending. 
For this research design to be effective, the border areas proximate to payday lending must be comparable to non-border areas, at least after controlling for observable differences. As measured by income and unemployment rates, the two areas are quite similar; if anything, households with payday loan access are slightly more prosperous. Demographically, areas with loan access are less populous, less urban and less racially diverse. To assure comparability, all regressions include controls for these differences. The analysis also includes additional tests to confirm that other county-level differences are not confounded with the difference in payday loan access. First, I confirm that the effect of payday lending on food stamp receipt is absent in mid-1990s, before payday loan stores had much of a presence. Second, I confirm that the effect of payday lending on food stamp receipt grows through time, as does payday loan availability.

This research relates most closely to the literature on payday lending and economic hardship (Carrell and Zinman 2011; Melzer 2011; Morgan and Strain 2008; Morse 2011; Skiba and Tobacman 2011), but also builds on work that analyzes food stamp usage (McKernan and Ratcliffe 2003; Wilde and Dicken 2003; Ratcliffe, McKernan and Finegold 2008) and child support delinquency (Heinrich, Burkhardt and Shager 2011; Cancian, Heinrich and Chung 2009). While the topic is quite different, the spirit of this inquiry parallels Autor, Dorn and Hanson (2011), who find that displaced workers do not bear all of the costs of dislocation after traderelated employment shocks, as they use transfer benefits to replace lost income. As noted earlier, studies of payday lending are not uniform in their conclusion that loan access aggravates financial hardship. Morgan and Strain (2009) find that bounced check volumes are lower before the prohibition of payday lending in North Carolina and Georgia. Morse (2011) finds that home foreclosures increase less following natural disasters if there is a payday loan store in the area. 
The disparity in findings may reflect heterogeneity in the effects of loan access, both across borrowers and across states of the world.

II. Background on Payday Lending, Nutrition Assistance Programs and Child Support

II.A. Payday Lending

Payday loans are small, short-term loans that evolved from check cashing transactions, as check cashers began to advance funds against personal checks (Stegman 2008). In a typical transaction, the borrower receives $\$ 350$ of cash in exchange for a promise to repay $\$ 400$ in two weeks. The transaction fee - in this example, $\$ 50$ - is typically around $15 \%$ of the loan amount. Underwriting is minimal: borrowers must have a bank account and must show a recent pay stub as evidence of employment.

Borrowers have low to moderate incomes, with the vast majority reporting $\$ 15,000$ to $\$ 50,000$ of annual income (Elliehausen and Lawrence 2001). In practice, payday loans are used for much longer periods than two weeks, as borrowers commonly renew or roll over loans. Both survey (Elliehausen and Lawrence 2001) and administrative data indicate that a substantial portion of borrowers, around one third, use payday loans on a recurring basis. For these borrowers, annual interest payments are substantial, amounting to $\$ 750$ to $\$ 1250$ per year.

Payday lending emerged in the mid- to late-1990s and grew substantially, reaching 25,000 store locations by 2006 . Annual loan volume is estimated to have grown in parallel, from about $\$ 8$ billion in 1999 to between $\$ 40$ and $\$ 50$ billion in 2004 (Stegman 2007). The industry is regulated at the state level, through check cashing, small loan and usury laws. Restrictions on fees, loan amounts and loan rollovers are typical, but several states have taken a more extreme position, enacting or enforcing a prohibition on payday lending. These states are crucial in this 
study, which makes use of cross-border access with prohibiting states. Over the study period, eight states prohibited payday loans for some period: Connecticut, Georgia, Maryland, Massachusetts, New Jersey, New York, North Carolina and Vermont. ${ }^{1}$

\section{II.B. Nutrition Assistance}

The Supplemental Nutrition Assistance Program (SNAP) is a federally funded transfer program that assists qualifying households in purchasing food. The program began in 1964 as the Food Stamp Program (FSP) and was re-titled as the Supplemental Nutrition Assistance Program in 2008 .

To qualify for SNAP, a household must pass income and asset tests. Those with monthly income below $130 \%$ of the Federal Poverty Level (FPL) qualify, as long as their assets (excluding primary residence and retirement savings) do not exceed $\$ 2,000$. The 2011 poverty level for a family of four is $\$ 22,350$ annually ( $\$ 1863$ monthly), which means that households with income below $\$ 29,055$ annually $(\$ 2,422$ monthly) qualify for food stamps as long as they lack $\$ 2,000$ in assets.

SNAP benefit payments also vary with income: a maximum allotment is set based on family size, and the benefit payment declines from that amount as household income rises. ${ }^{2}$ In 2011 , the maximum monthly benefit for a family of four is $\$ 668$, which translates to a benefit payment of $\$ 368$ at monthly income of $\$ 1,000$ or $\$ 110$ at monthly income equal to $\$ 1863$, the Federal Poverty Level. The average monthly benefit per participant was $\$ 134$ in 2010 . Benefits

\footnotetext{
${ }^{1}$ Connecticut, Massachusetts, New Jersey, New York and Vermont prohibited payday loans for the entire sample period. Georgia, North Carolina and Maryland prohibited lending during the sample period, in 2004, 2006 and 2002, respectively.

${ }^{2}$ The formula for the benefit payment: benefit $=\max (0$, maximum allotment $-0.3 *($ monthly income $))$.
} 
are paid monthly as credits to an Electronic Benefits Transfer account that is accessed by means of a payment card.

An average of 22 million people per year, roughly $10 \%$ of the adult population, used food stamps between 1996 and 2007. Total annual benefits averaged $\$ 259$ billion over this period, reaching $\$ 364.5$ billion in 2007 . Benefits per participant, measured in real terms, stayed fairly constant throughout the entire period, at around $\$ 70$ per month (in 2000 dollars). Participation in the FSP fell considerably between 1996 and 2000, from 25.5 million participants to 17.2 million participants, but recovered to 26.3 million by 2007 . Much of this variation was driven by changes in participation rates rather than eligibility rates. Studies of SNAP eligibility and take-up show household participation rates between $48 \%$ and $62 \%$, at the low end of the range in the early 2000s and the high end of the range in 1996 and 2006. Estimated participation rates also vary considerable across states, from a low of $53 \%$ in California to a high of $99 \%$ to $100 \%$ in Oregon and Maine.

\section{II.C. Child Support}

Child support orders, which mandate the financial support of children by nonresident parents, are put in place to ensure the well-being of children in single parent households. Particularly for low-income families, child support payments are an important source of income: among families below the poverty level that receive child support, those payments constitute one third of income (Sorenson and Oliver, 2002). Support payments are legal obligations, established through a court or administrative hearing process, which are not dischargeable in bankruptcy. However, despite this legal status unpaid child support is a big problem: the federal Office of Child Support Enforcement reported total child support debt of $\$ 105$ billion as of September, 
2006. As with food stamp participation, child support policies governing award determination and enforcement differ substantially across states.

III. Data, Measures and Methods

III.A. Data

The Census Bureau's Survey of Income and Program Participation (SIPP) is the primary data source for this analysis. The SIPP is a longitudinal survey that tracks household well-being and public program participation over a four year period. During that time, participants are interviewed every four months, with "core wave" information on income, employment and transfer program participation collected in every interview and "topical module" information on economic hardship, wealth and child support payments, among other topics, collected at lower frequency. The initial sample of roughly 40,000 households is designed to oversample lowincome households for whom program participation is most likely, but is otherwise nationally representative and covers all 50 states. $^{3}$

This analysis uses the 1996, 2001 and 2004 SIPP Panels, which provide data for 1996 through the end of 2007. The analyses of economic hardship and child support use the Adult Well-being and Child Support Paid Topical Modules, while the analysis of food stamps uses Core Wave information. Detailed geographic information, which is used to measure distance to payday lending, is unavailable in the SIPP public use files, so the analysis uses non-public use data warehoused in the Census Research Data Center.

\footnotetext{
${ }^{3}$ Households are split evenly into high- and low-income groups based on decennial Census information and the lowincome group is sampled at 1.66 times the rate of the high-income group.
} 
The SIPP data are merged with the following county-level data: economic and demographic information from the 2000 Census, monthly unemployment rates from the Bureau of Labor statistics and annual personal income information from the Bureau of Economic Analysis.

\section{III.B. Key Variables and Summary Statistics}

\section{III.B.1. Measuring Payday Loan Access}

The primary independent variable is PaydayAccess, a measure of geographic proximity to payday lending. Payday Access is an indicator variable which is one for households located less than 25 miles from a payday-allowing state, and zero otherwise. Household location is determined by county of residence. An important feature of this measure of loan access is that it is not affected by the endogenous location decisions of lenders. For robustness, additional models use a continuous measure of payday loan access: $\log$ (Payday Distance), which is the natural logarithm of the distance to the nearest payday allowing state.

\section{III.B.2. Economic Hardship, Food Stamps and Child Support}

The first phase of the analysis examines the relationship between payday loan access and economic hardship. To measure economic hardship, the SIPP includes a battery of questions about the household's ability to afford essential items and pay important bills over the prior four or twelve months. The questions about food-related hardship, which are of particular interest, are coded into three indicator variables. Food Shortage takes the value of one if the household's food didn't last over and they couldn't afford more over the prior four months. Cut Meals (adult) takes the value of one if the adults cut the size of meals or skipped meals due to lack of money. Analogously, Cut Meals (children) is one if the children were not eating enough because the 
household couldn't afford more food, or zero otherwise. The questions about non-food expenditures are summarized in a single indicator variable. Any Hardship takes the value of one if the household was unable to pay its mortgage, rent or utilities bills or if anyone in the household failed to get needed dental or medical care over the prior twelve months.

The second phase of the analysis examines food stamp utilization, using both an indicator variable for receipt (FS received) and a continuous variable (FS Amount) for the dollar amount of benefits received. Though food stamp information is collected for every month, I follow the literature in dropping observations outside of the interview month. As a result the dependent variable is a measure of monthly food stamp usage at a frequency of every four months. The rationale for this adjustment to the sample is that there tend to be substantial jumps in survey reports at the "seam" between interviews, seemingly because households recall food stamp usage in the most recent month most clearly and repeat that response for prior months for which they don't recall their usage.

The third phase of the analysis examines child support payments. CS Payment Required? and CS Paid? are indicator variables, the first measuring whether anyone in the household were required to pay child support and the second measuring whether any payments were made. Finally, CS Paid Amount measures the dollar amount of child support paid by the household over the prior twelve months.

III.B.3. Economic and Demographic Characteristics of Areas with Payday Loan Access

Table I displays sample statistics for a variety of economic and demographic variables. The sample is limited to counties or households in payday-prohibiting states and stratified by 
Payday Access, in order to examine whether border areas with nearby payday loan access are otherwise comparable to areas with less proximate payday loan access.

County-level data indicates that, on average, Payday Access areas are more prosperous, with lower rates of unemployment and slightly higher per capita income: $4.4 \%$ unemployment rate and $\$ 36,100$ per capita income compared to $4.8 \%$ and $\$ 35,400$ among non-access counties. Payday Access areas are also less populous and more rural: the average 2000 Census population in an access area is 150,000 with $50 \%$ urban population, compared to an average population of 250,000 in non-access areas, $60 \%$ of which is in an urban area.

Household-level summary statistics for the regression sample (below $\$ 4,166$ in monthly income), shown in Panel B, confirm that even within the low- to moderate-income group, households with Payday Access appear to be more prosperous. They have higher monthly income ( $\$ 2,100$ vs. $\$ 2000)$ and higher rates of home ownership (58\% vs. $46 \%)$, and they are slightly less likely to be unemployed (5.4\% vs. $5.5 \%)$ or uninsured (19\% vs. $21 \%)$. Educational attainment is modestly higher in Payday Access areas, largely due to a higher proportion of households with at least a high school diploma or some college experience. Disparities in racial/ethnic composition are more striking, with fewer minorities in Payday Access areas: the proportion of black households is $14 \%$, compared to $19 \%$ in areas without access, and the proportion of Hispanic households is $3 \%$, compared to $12 \%$ in areas without access. In other household characteristics like number of children, household size and householder age there is little difference between access and non-access areas.

To summarize, the sample statistics show economic and demographic differences between areas with and without payday loan access. These differences are important to keep in 
mind for the regression analysis of food stamp usage. While the regressions will include controls for all of these observable differences, one might have concerns that the controls are inadequate, and that omitted characteristics may diverge similarly between the two areas. McKernan and Ratcliffe (2003) show that food stamp usage tends to rise with unemployment, as one would expect. Notably, the observable differences in unemployment and income would predict lower food stamp usage in Payday Access areas.

\section{Regression Analysis}

The regression analysis uses the following model:

$$
y_{i c s t}=\alpha+\beta \text { Payday } \text { Access }_{c t}+X_{i t}+Z_{c t}+\gamma_{s t}+\varepsilon_{i c s t}
$$

$\beta$ is the coefficient of interest. All specifications include state-year fixed effects, denoted by $\gamma$, so that $\beta$ is not identified from cross-state differences in hardship or state-level changes in hardship over time. All models include a vector of household-level controls, denoted by X, and a vector of county-level controls, denoted by Z. All household-level variables are listed in the table of summary statistics (Table I). The county-level controls include three static measures from the 2000 Census - county median income, population and percent urban population - as well as Border, an indicator for whether the household is located within 25 miles of a state border. Z also includes two time-varying controls, the county's unemployment rate and per capita personal income. These county-level controls are crucial because Payday Access varies at the county level.

IV.A. Payday Access and Economic Hardship 
This section replicates the analysis of Melzer (2011) in the SIPP sample. Melzer uses data from the National Survey of America's Families (NSAF). The SIPP's survey questions are quite similar, but its sample includes a longer time series - covering 1996 through 2007, whereas the NSAF data ended in 2001 - and greater geographic coverage - the NSAF data cover thirteen "focal" states whereas the SIPP survey covers all states in proportion to their population. The extended time series expands the number of prohibiting states analyzed, since states like Maryland, Georgia and North Carolina prohibited payday loans between the end of the NSAF sample and the end of the SIPP sample.

The regression results, shown in Table II, reveal higher incidence of economic hardship in Payday Access areas. Households with cross-border loan access are 4.0 percentage points more likely to report Any Hardship, which encompasses difficulty in affording health care and in paying important bills for shelter and utilities. This difference is statistically significant at the 5\% level and represents a $16 \%$ increase in hardship relative to the average incidence of $24.9 \%$ across all households in the sample. In contrast, two of the three measures of food-related hardship display much smaller and statistically insignificant coefficients Payday Access. The point estimate for Food Shortage indicates higher incidence in Payday Access areas (39 basis point increase), but the confidence interval is quite wide. For Cut Meals (adult) and Cut Meals (children) the point estimates are smaller: 41 and -1 basis points, respectively. These findings greater difficulty in paying important bills, but little difference in food-related hardship - match Melzer's results in the NSAF sample.

IV.B. Payday Access and Food Stamps 
Results for the regression analysis of food stamps, shown in Table III, indicate that food stamp usage is higher among households with payday loan access. The first two columns show estimates for the sample of households with less than $\$ 50,000$ of income. Among those households, food stamp receipt is 2.0 percentage points more prevalent in payday access areas, a 20 percent increase relative to the average. The dollar amount of food stamps received shows a similar difference: monthly food stamp receipt is higher by $\$ 4.21$ in Payday Access areas, a 20\% increase over the $\$ 21.50$ monthly average in the regression sample. Each of these specifications controls for food stamp eligibility as well as other important individual and county-level predictors of food stamp participation. In the last two columns of Table III, the regression sample is restricted to food stamp-eligible households. Though the level of food stamp receipt and the coefficients on Payday Access are higher in this sample, the relative increase in food receipt is similar to the first two specifications: roughly $20 \%$ higher food stamp utilization in Payday Access areas.

Consistent with Meyer, Mok and Sullivan (2008), who document systematic underreporting of transfer program participation in household surveys, I find lower rates of participation and lower average benefit levels than administrative data imply. Thirty one percent of eligible household-months include food stamp receipt, whereas administrative records suggest participation rates of fifty to sixty percent.

\section{IV.C. Payday Loan Access and Child Support}

Table IV displays the regression results for child support payments. Roughly $4 \%$ of sample households report that they are required to make child support payments, with no significant difference based on Payday Access. Though the requirement to pay child support does 
not seem to vary with payday loan access, delinquency does. As shown in the second column, households with Payday Access are 30 basis points less likely to make a payment, a 10 percent decline relative to the sample average of $3 \%$. The dollar value of payments also declines: annual payments are $\$ 8$ lower among households with loan access, a decline of roughly $25 \%$ relative to the $\$ 30$ average. These coefficients and averages are quite small because the sample includes the $96 \%$ of households that are not required to make payments (the regressions include CS Payment Required? as a control). Dropping those households has little effect: the final two models confirm that among households required to pay child support, Payday Access households make fewer payments.

IV.D. Payday Access Effects over Time

Table V shows how the correlation of Payday Access and food stamps receipt varies over time. Payday lending emerged in the mid- to late-1990s, with dramatic growth through 2006 or 2007. Thus, in the early part of the sample, when loan volumes were substantially lower and store locations were more sparse, we would expect smaller coefficients on Payday Access. The results support this hypothesis: the effect of Payday Access on food stamp participation is smallest and statistically insignificant in the years 1996 to 1998, and the effect grows over time.

\section{Discussion}

Taking income and family size - the two most important inputs in determining food stamp eligibility - to be largely exogenous to payday borrowing, the effects of payday lending on food stamps must operate through take-up. Borrowers take on a large debt service burden, an increase in expenses that can crowd out other expenditures over time and lead households to sign up for food stamps. 
County-level unobservables are a concern for the research design. For example, one might worry that social safety net services differ systematically in Payday Access areas. Following this line of thinking, one would explain the finding of greater economic hardship in Payday Access by postulating inferior safety net programs in those areas. The findings on food stamps indicate otherwise, however, as food stamp participation is actually higher in Payday Access areas. Furthermore, if households in Payday Access counties were worse off in general, one would expect the same disparity in hardship in the early part of the sample, before payday loans were widely available. Yet the pattern in food stamp participation over time matches the pattern of payday loan availability over time.

VI. Conclusion

Recent research on the effects of credit access among low-income households finds that high-cost payday loans exacerbate financial distress for some borrowers, leading to increased difficulty paying mortgage, rent and utilities bills (Melzer 2011) and increased risk of bankruptcy (Skiba and Tobacman 2011). This paper asks whether payday lending affects others outside the borrowing household. To gauge such spillover costs, I examine food stamp participation and child support payments, and find that households with proximate access to payday lending are more likely to use food stamps and less likely to pay required child support. These findings suggest that the burden of costly payday credit is not limited to borrowers, but spills over to taxpayers who fund food stamp programs and non-resident family members who depend on child support payments. 


\section{References}

Almond, Douglas, Hilary Hoynes and Diane Whitmore Schanzenbach. 2011. Inside the War on Poverty: The Impact of the Food Stamp Program on Birth Outcomes. Review of Economics and Statistics 93(2): 387-403.

Ausubel, Lawrence M. 1991. The Failure of Competition in the Credit Card Market. American Economic Review 81(1): 50-81.

Autor, David H., David Dorn and Gordon H. Hanson. 2011. The China Syndrome: Local Labor Market Effects of Import Competition in the United States. MIT Working Paper.

Bond, Philip, David K. Musto and Bilge Yilmaz. 2009. Predatory Mortgage Lending. Journal of Financial Economics, 94(3): 412-427.

Campbell, John Y., Stefano Giglio, and Parag Pathak. 2011. Forced Sales and House Prices. American Economic Review, 101(5): 2108-2131.

Cancian, Maria, Carolyn Heinrich and Yiyoon Chung. 2009. Does Debt Discourage Employment and Payment of Child Support? Evidence from a Natural Experiment. La Follette School Working Paper No. 2009-012

Carrell, Scott, and Jonathan Zinman. 2008. In Harm's Way? Payday Loan Access and Military Personnel Performance. Working Paper.

Heinrich, Carolyn J., Brett C. Burkhardt and Hilary M. Shager. 2011. Reducing Child Support Debt and Its Consequences: Can Forgiveness Benefit All? Journal of Policy Analysis and Management 30(4): 755-774

Hoynes, Hilary and Diane Whitmore Schanzenbach. 2009. Consumption Responses to In-Kind Transfers: Evidence from the Introduction of the Food Stamp Program. American Economic Journal-Applied Economics 1(4): 109-139. 
Hoynes, Hilary and Diane Whitmore Schanzenbach. 2012. Work Incentives and the Food Stamp Program. Journal of Public Economics 96(1-2): 151-162.

Laibson, David. 1997. Golden Eggs and Hyperbolic Discounting. Quarterly Journal of Economics 62: 443-477.

Melzer, Brian T. 2011. The Real Costs of Credit Access: Evidence from the Payday Lending Market. Quarterly Journal of Economics 126(1), 517-555.

McKernan, Signe-Mary and Caroline Ratcliffe. 2003. Employment Factors Influencing Food Stamp Program Participation. The Urban Institute, Research Report.

Morgan, Donald P. and Michael R. Strain. 2008. Payday Holiday: How Households Fare after Payday Credit Bans. Federal Reserve Bank of New York Staff Reports, Number 309.

Morse, Adair. 2011. Payday Lenders: Heroes or Villains? Journal of Financial Economics 102(1): 28-44.

Ratcliffe, Caroline, Signe-Mary McKernan and Kenneth Finegold. 2008. Effect of State Food Stamp and TANF Policies on Food Stamp Program Participation. The Urban Institute, Research Report.

Skiba, Paige Marta, and Jeremy Tobacman. 2011. Do Payday Loans Cause Bankruptcy? Working Paper.

Whitmore, Diane. 2002. What are Food What Are Food Stamps Worth? Working Paper \#468, Princeton University Industrial Relations Section. 


\section{Table I: Summary Statistics}

Diff

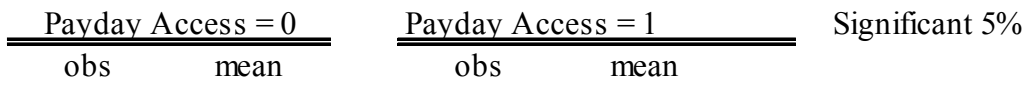

Panel A: County characteristics

Unemployment rate (\%)

Personal income per capita

Median income

Population

Percent urban population

$\begin{array}{rr}7389 & 4.82 \\ 7389 & 35,400 \\ 172 & 42,700 \\ 172 & 240,600 \\ 172 & 59.4\end{array}$

$\begin{array}{rr}3247 & 4.44 \\ 3247 & 36,100 \\ 118 & 41,100 \\ 118 & 147,800 \\ 118 & 49.5\end{array}$

Panel B: Household characteristics

Income/Assets

Monthly income

Homeowner?

50252

50252

2,001

0.46

17272

50252

Employment/Insurance

Unemployment spell?

50252

Uninsurance spell?

50252

0.055

17272

17272

17272

0.21

17272

2,109

0.58

0.054

0.19

Education

Less than HS

50252

0.17

17272

50252

HS degree

Some college

50252

0.34

17272

17272

50252

0.30

17272

College

50252

0.12

17272

17272

0.13

0.34

0.34

0.12

0.07

Race/Ethnicity

White

Black

Hispanic

50252

50252

50252

Asian/Other

50252

0.65

17272

17272

17272

17272

0.79

0.14

0.03

0.04

Other

Age

50252

HH size

50252

Number of children

50252

54.0

17272

17272

17272

$\begin{array}{ll}54.8 & * \\ 2.08 & * \\ 0.50 & *\end{array}$

Notes: Sample in both panels limited to observations from payday-prohibiting states; sample for household characteristics is also limited to those with monthly income below $\$ 4,166$. 


\section{Table II: Economic Hardship and Payday Loan Access}

(1)

Any Hardship Food Shortage

mean DV:

Payday Access

Border

Ln(Income)

Unemployment spell

Uninsured spell

$\mathrm{N}$

$\mathrm{R}^{2}$

County controls?*

Individual controls?**

State-year fixed effects?

0.040

0.025

0.0039

(0.007)

$-0.008$

$(0.007)$

$-0.002$

$(0.002)$

$-0.13$

(0.01)

0.12

(0.01)

0.16

$(0.01)$

$-0.03$

(0.003)

0.04

(0.01)

0.02

(0.002)

37,000

0.05

Y

Y

Y
(3)

(4)

Cut Meals (Adults)

0.046

Cut Meals (Children)

0.0041

(0.009)

$-0.005$

$(0.003)$

$-0.05$

$(0.004)$

0.04

(0.01)

0.03

(0.003)

40,000

0.05

Y

Y

$\mathrm{Y}$

0.003

$-0.0001$

(0.001)

$-0.001$

(0.001)

0.003

(0.001)

0.01

(0.003)

0.001

(0.001)
40,000

0.01

Y

Y

Y

*County controls: cubics in median income, population and pct. urban population; $\ln ($ personal income); unemployment rate

**Individual controls: number of HH members; number of children; home ownership; and indicator variables for education ( 5 categories) and for race (4 categories)

Notes: Number of observations in each regression rounded down to nearest thousdand; standard errors, given in parentheses, are clustered by county; coefficient estimates do not use regression weights. 


\section{Table III: Food Stamp Usage and Payday Loan Access}

(1)

$\begin{array}{ccc} & \text { FS Received? } & \text { FS Amount } \\ \text { mean DV: } & 0.11 & 21.5 \\ & 0.020 & 4.21 \\ & (0.009) & (2.30) \\ & 0.219 & 34.6 \\ & (0.005) & (0.91) \\ & -0.0005 & -0.5 \\ & (0.003) & (0.68) \\ & 0.006 & -1.85 \\ & (0.001) & (0.40) \\ & 0.05 & 22.2 \\ & (0.004) & (1.1) \\ & -0.04 & -5.87 \\ & (0.003) & (0.80) \\ & 477,000 & 477,000 \\ & 0.25 & 0.25 \\ & \mathrm{Y} & \mathrm{Y} \\ \mathrm{Y} & \mathrm{Y} \\ \mathrm{Y} & \mathrm{Y}\end{array}$

(3)

(4)

FS Received? FS Amount

$0.31 \quad 61.1$

Payday Access

Food stamps eligible?

Border

Ln(Income)

Unemployment spell

Uninsured spell

$\mathrm{N}$

$\mathrm{R}^{2}$

County controls?*

Individual controls?**

State-year-month fixed effects?
0.063

(0.019)

12.7

(6.0)

$0.001 \quad-0.72$

(0.008) (1.74)

$0.001 \quad-6.0$

$(0.002) \quad(0.55)$

$0.07 \quad 30.8$

(0.01) (1.9)

$-0.11 \quad-19.8$

$(0.01) \quad(1.7)$

$145,000 \quad 145,000$

$0.22 \quad 0.30$

Y Y

$\mathrm{Y} \quad \mathrm{Y}$

Y Y

*County controls: cubics in median income, population and pct. urban population; $\ln$ (personal income); unemployment rate

**Individual controls: number of HH members; number of children; home ownership; and indicator variables for education ( 5 categories) and for race (4 categories)

Notes: Number of observations rounded down to nearest thousand in each regression; sample in columns (4) and (5) is restricted to food stamp-eligible households; standard errors, given in parentheses, are clustered by county; coefficient estimates do not use regression weights. 


\section{Table IV: Child Support Payments and Payday Loan Access}

(1)

\begin{tabular}{|c|c|c|c|c|c|}
\hline mean DV: & $\begin{array}{c}\text { CS Payment Required? } \\
0.04\end{array}$ & $\begin{array}{c}\text { CS Paid? } \\
0.03\end{array}$ & $\begin{array}{c}\text { CS Paid Amount } \\
30.4\end{array}$ & $\begin{array}{c}\text { CS Paid? } \\
0.79\end{array}$ & $\begin{array}{c}\text { CS Paid Amount } \\
811.2\end{array}$ \\
\hline Payday Access & $\begin{array}{c}0.005 \\
(0.004)\end{array}$ & $\begin{array}{l}-0.0032 \\
(0.0018)\end{array}$ & $\begin{array}{l}-8.03 \\
(3.63)\end{array}$ & $\begin{array}{l}-0.095 \\
(0.058)\end{array}$ & $\begin{array}{l}-234.5 \\
(99.9)\end{array}$ \\
\hline CS Payment Required? & & $\begin{array}{c}0.79 \\
(0.01)\end{array}$ & $\begin{array}{l}810.9 \\
(13.4)\end{array}$ & & \\
\hline Border & $\begin{array}{l}-0.004 \\
(0.002)\end{array}$ & $\begin{array}{c}0.001 \\
(0.001)\end{array}$ & $\begin{array}{c}1.12 \\
(1.10)\end{array}$ & $\begin{array}{c}0.03 \\
(0.02)\end{array}$ & $\begin{array}{c}23.6 \\
(29.4)\end{array}$ \\
\hline Ln(Income) & $\begin{array}{c}0.03 \\
(0.002)\end{array}$ & $\begin{array}{c}0.001 \\
(0.001)\end{array}$ & $\begin{array}{c}7.06 \\
(1.41)\end{array}$ & $\begin{array}{c}0.026 \\
(0.023)\end{array}$ & $\begin{array}{l}189.5 \\
(39.1)\end{array}$ \\
\hline Unemployment spell & $\begin{array}{c}0.02 \\
(0.004)\end{array}$ & $\begin{array}{c}-0.01 \\
(0.002)\end{array}$ & $\begin{array}{l}-14.0 \\
(2.7)\end{array}$ & $\begin{array}{l}-0.08 \\
(0.03)\end{array}$ & $\begin{array}{l}-148.5 \\
(38.4)\end{array}$ \\
\hline Uninsured spell & $\begin{array}{c}0.02 \\
(0.002)\end{array}$ & $\begin{array}{l}-0.003 \\
(0.001)\end{array}$ & $\begin{array}{l}-4.44 \\
(1.15)\end{array}$ & $\begin{array}{l}-0.04 \\
(0.01)\end{array}$ & $\begin{array}{l}-51.2 \\
(25.5)\end{array}$ \\
\hline $\mathrm{N}$ & 98000 & 98000 & 92000 & 4000 & 3000 \\
\hline $\mathrm{R}^{\wedge} 2$ & 0.03 & 0.25 & 0.62 & 0.18 & 0.20 \\
\hline County controls?* & $\mathrm{Y}$ & $\mathrm{Y}$ & Y & $\mathrm{Y}$ & $\mathrm{Y}$ \\
\hline Individual controls?** & $\mathrm{Y}$ & Y & Y & $\mathrm{Y}$ & Y \\
\hline State-year fixed effects? & $\mathrm{Y}$ & Y & Y & $\mathrm{Y}$ & Y \\
\hline
\end{tabular}

Notes: Number of observations rounded down to nearest thousand in each regression; sample in Columns (4) and (5) is restricted to households required to pay child support; standard errors, given in parentheses, are clustered by county; coefficient estimates do not use regression weights. 


\section{Table V: Food Stamp Usage and Payday Loan Access Over Time}

Payday Access

Border

$\operatorname{Ln}($ Income $)$

Unemployment spell

Uninsured spell

$\mathrm{N}$

$\mathrm{R}^{\wedge} 2$

County controls?*

Individual controls?**

State-year-month fixed effects?
(1) FS Received?

(2)

FS Received? 1999-2001 Sample: 1996-1998

$-0.045$

(0.041)

0.021

(0.01)

$-0.010$

$(0.003)$

0.09

(0.01)

$-0.12$

(0.01)

53000

0.23

\section{Y}

$\mathrm{Y}$

Y

0.003

(0.03)

0.017

(0.01)

$-0.012$

(0.003)

0.08

(0.01)

$-0.12$

(0.01)

33000

0.21

Y

Y

Y
(3)

(4)

FS Received? FS Received?

2002-2004 2005-2007
0.086

(0.023)

$-0.009$

(0.009)

$-0.0004$

(0.002)

0.07

(0.01)

$-0.11$

(0.01)

51000

0.22

Y

Y

Y
0.088

(0.026)

$-0.011$

(0.012)

0.01

(0.002)

0.06

(0.01)

$-0.10$

(0.01)

44000

0.22

Y

Y

Y

*County controls: cubics in median income, population and pct. urban population; $\ln$ (personal income); unemployment rate.

**Individual controls : number of $\mathrm{HH}$ members; number of children; home owners hip; and indicator variables for education ( 5 categories) and for race (4 categories).

Notes: Number of observations rounded down to nearest thousand in each regression; sample is restricted to food stamp-eligible households; standard errors, given in parentheses, are clustered by county;

coefficient estimates do not use regression weights. 